\title{
The Infanticide: Some Forensic and Ethical Issues
}

\section{Argo $\mathrm{A}^{*}$ and Francomano $\mathrm{A}^{2}$}

${ }^{1}$ Department of Medical Biotechnology and Forensic Medicine, University of Palermo, Italy

${ }^{2}$ Department of Psychiatry, University of Palermo, Policlinic Hospital, Italy

${ }^{*}$ Corresponding author: Argo A, Associate Professor, Department of Medical Biotechnology and Forensic Medicine, University of Palermo, Italy; E-mail: antonella.argo@libero.it

Citation: Argo A, Francomano A (2013) The Infanticide: Some Forensic and Ethical Issues. J Forensic Sci Criminol 1(1): e102. doi: 10.15744/2348-9804.1.e102

Received Date: July 01, 2013 Accepted Date: July 29, 2013 Published Date: August 01, 2013

\begin{abstract}
Forensic investigation and clinical treatment of infanticide mother is an occasion to reflect about the social stigma associated with this crime. The forensic-psychiatric assessment must be anchored on an authentic and meaningful clinical relationship to criminal mother, without misinterpretation and countertransferal dynamics, such as emotional reactions of mistrust and stigmatization of the offender. These prevent the evaluator from making a correct psychological and psychopathological diagnosis. There is evidence that diachronic, multidisciplinary diagnostic evaluation may lead to strategies for treatment and rehabilitation. These measures, which can allow the patient to regain his dignity, his working capacities and social role, and ensure that the penalty is rehabilitative and not only retributive.
\end{abstract}

Keywords: Infanticide; Psychodiagnosis; Rehabilitation; Stigmatization

\section{Introduction}

Infanticide is a crime resulting in social stigma and alarm. Accordingly to the penal rules of most countries, perpetrators of this crime may be only the mother who kills her newborn son while it is being born. Psychological element of this offense requires a general intent in the conscience and will of the mother to suppress her newborn infant or fetus, in a state of moral and material abandonment. The offense may be either that of commission or omission, coupled with the element of concealment. With regard to the mode of killing, analysis of the Italian data (2000-2005) shows a prevalence of murders with asphyxiated mechanisms (19\% drowning, suffocation and strangulation $18 \%, 10 \%)$, by defenestration (15\%), with wound gunshot and cutting tip (15\%) and, less frequently, with a firearm $(4 \%)$. The murder site is mainly at home (85\%), and in particular bathroom (64\%) and bedroom (20\%) [1]. Studies defined a number of types of situations and reasons for maternal filicide. The first extensive report about the parents filicide was drafted in 1969 by Resnick [2], who examined 131 cases reported in the world literature between 1951 and 1967.

The five prevailing psychological patterns of filicide are:

- The altruistic (also known as murder pietatis cause or compassionate) [3] often characterized by Beck's syndrome, consisting of a pessimistic view of self, the world, their own future and his son [1];

- The high-psychotic, where the crime is conducted under the pressure of imperative hallucinations;

- Killing in which the mother is faced with unwanted parenthood, the result of an extramarital affair or mother 's inability to face severe pain, abandonment, violence;
-The revenge on her father, better known as Medea complex [4];

- Accidental death [5] is, however, one of the most dramatic events of the abused child syndrome or Battered Child Syndrome, in which the mother causes the death of his son during an impulsive act initiated by the crying or screaming of the child.

Numerous other studies on infanticide mothers have been published since Resnick offered classifications based on motivation, clinical situations, and the origin of the impulse to kill [6-8].

Other types of filicide that must be considered are the negligent, passive omissions of mothers, who do not cater adequately to the needs of their child (for food, protection, even physical-use of proper clothing to the temperature-and medical care). In certain other cases the mothers who kill their children as surrogate scapegoats on which to vent their frustrations. Alternatively, the offense is the child's desire to kill his own mother [9]. Other mothers experience hysteria during pregnancy and "transform waste" the newborn [10] using a primitive defense mechanism that "helps to avoid the awareness of aspects of external reality difficult to deal with". It has been said that "these women are pregnant with a 'nuisance' that will ultimately be disposed of in the trash or in the toilet bowl" [11]. 


\section{Discussion}

\section{Criminological patterns}

Neonaticide is most frequently committed by very young mothers (often under the age of twenty-five years old), immature, unmarried, unemployed or still students; they not feel able to deal with the responsibilities and stress social motherhood entails [12]. These are young women who generally do not maintain stable relations with the father of their children and do not seek prenatal care [13]. Frequently childbirth is carried out at home or in other non-hospital settings, although recorded cases of neonaticide in neonatal warn-hospitals have occurred [14]. Often the same offense is preceded by the denial of pregnancy, to the point that even the woman herself is surprised by the appearance of contractions [10]. Women who commit neonaticide, frequently describe dissociative symptoms, such as depersonalization, derealization, and dissociative hallucinations [15]. Women, however, rarely suffer from a serious mental disorder at the time of the crime $[16,17]$.

Spinelli [18] has shown how those who commit the crime are often raised in environments characterized by emotional neglect, isolation, and confusion where the roles and limits of behavior are violated. These women suffered from the lack of supportive parental models, whose mothers had minimal emotional involvment with their raising, often due to intercurrent diseases or the use/abuse of substances. Many were forced to assume the responsibilities of absent parents. Among women neonaticide and infanticide (groups that are very similar to each other) the issue is simply rejection of a 'unwanted child', while for filicide the reason is even more significant mental distress compared with psychosocial factors $[7,19,20]$. Other features typical of figlicide is often greater than the age of 25 years, generally be married, having a good education [2]. These women also have a tendency to premeditate his crime, as well as fulfill the gesture as revenge against another person, also believed to have been abused or ill-treated [5].

\section{Risk factors and mental disorders}

In the analysis of infanticide mothers three indicators of risk are were particularly important: the personality structure of the perpetrator of the crime, the relationship with the original family (especially the mother) and the relationship with the partner. Often these women have experienced various forms of abuse, from sexual to the emotional, with the tendency to suppress their emotions, in familiar contexts dominated by the absence of a father figure, with awkward presence of intrusive mothers, neglectful and often suffering from severe mood disorders [1]. Because the ability of the mother to look after the child is the result of lessons learned from his mother, it is as if these women were victims of a murder is not embodied in physical terms, but definitely made in terms of emotions, resilience and coping skills.

It could, therefore, say that infanticide is a transgenerational crime. When a mother kills her child is, not infrequently, a strong expectation of "abnormality" or perhaps, a bias of ab- normality, since this crime violates the customs of psychic normality on which we rely, but it is even considered "against nature" [21,22]. In forensic psychiatric practice is has been observed, however, that the filicide may occur in relation to processes that are not necessarily influenced by the presence of diseases or mental disorders can lead to a noticeable impairment of the ability of discernment.

The studies about mental disorders suffered by murderous mothers, inevitably carried out on small patients group, showed conclusions sometimes dissonant. Krischer, et al. [23] in his study identified two major groups of mental disorders, the most represented falling within the Schizophrenic spectrum (about 63\%), including Schizophrenia (42\%), Schizoaffective Disorder (14\%), or Paranoid (7\%), as opposed to the spectrum of affective disorders (another $30 \%$ ), which includes major depression (12.3\%), Depression with psychotic symptoms (10.5\%), and post partum (3.5\%), and Bipolar Disorder (3.5\%). In contrast, in the study by Haapasalo and Petaja [24] maternal infanticide in the diagnosis of major depression constituted over $82 \%$. Offenders also often manifest axis II comorbidity, especially for cluster B personality disorders, borderline, antisocial, often in association with alcohol dependence [25].

\section{Evaluation of the infanticide mother for the treat- ment of recovery}

The psycho-diagnostic tests are fundamental aid to psychiatric diagnosis, both in clinical and forensic approach. Usually, the commitment asked the forensic-psychiatric professionals to go beyond the mere nosographic description, ensuring that the Court may apply the standards required by the penal code. In this field of observation, the adoption of specific procedures of observation can provide useful ideas and suggestions to propose a project or set of rehabilitation treatment, ethically significant.

The clinical interview is an important opportunity for an existential encounter that can recognize and return to the criminal their dignity as a person, and is the focus necessary for development of diagnostics measures to be structured according to a defined methodology, geared to descriptive neutrality and based on personal skills and convergence of multiple structures and professionalism.

Until recently, forensic expert, therefore, against the offender, acts and reacts not only emotionally, but also culturally and socially [22]. Consequently, he has a moral obligation to promote consciously and responsibly communication, considering the "other" (infanticide mother) as a person with an history rich in meaning and not to be questioned or prevented with enough attitude. Unfortunately, a crime such as infanticide evokes strong counter transferal dynamics, producing emotional reactions of distrust, contempt and stigmatization of the offender, which considerably hamper the understanding of psychological and psychopathological aspects. To avoid that women author of infanticide under investigation suffer these dynamics, any anti-transferal reactions will be discussed and developed within a therapeutic staff and su- 
pervision work (both individual and group).

\section{References}

1. Mastronardi VM, Villanova M (2007) Mothers who kill. The chilling and desperate voices of more than three hundred women who murdered their children. Newton Compton Editori Roma.

2. Resnick PJ (1969) Child murder by parents: A psychiatric review of filicide. American Journal of Psychiatry 126: 325-334.

3. Farooque R, Ernst FA (2003) Filicide: A review of eight years of clinical experience. J Natl Med Assoc 95: 90-4.

4. Lambie I (2001) Mothers who kill. The crime of infanticide. Int J Law Psychiatry 24: 71-80.

5. D Orban PT (1979) Women who kill their children. British Journal of Psychiatry 134: 560-71.

6. Bourget D, Bradford JM (1990) Homicidal parents. Can J Psychiatry 35: 233-8.

7. Bourget D, Gagne P (2002) Maternal filicide in Quebec. J Am Acad Psychiatry Law 30: 345-51.

8. Scott PD (1973) Parents who kill their children. Med. Sci. Law 13: 120-6.

9. Crimmins S, Langley S, Brownstein HH, Spunt BJ (1997) Convicted women who have killed children: A self-psychology perspective. Journal of Interpersonal Violence 12: 49-69.

10. Green CM, Manohar SV (1990) Neonaticide and hysterical denial of pregnancy. Br J Psychiatry 156: 121-3.

11. Brozovsky M, Falit H (1971) Neonaticide. Clinical and psychodynamic considerations. J Am Acad Child Psychiatry 10: 673-83.

12. Overpeck MD, Brenner RA, Trumble AC, Trifiletti LB, Berendes HW (1998) Risk factors for infant homicide in the United States. N Engl J Med 339: $1211-6$
13. Emerick SJ, Foster LR, Campbell DT (1986) Risk factors for traumatic infant death in Oregon, 1973-1982. Pediatrics 77: 518-22.

14. Mendlowicz MV, da Silva Filho JF, Gekker M, de Moraes TM, Rapaport $\mathrm{MH}$, et al. (2000) Mothers murdering their newborns in the hospital. Gen Hosp Psychiatry 22: 53-5.

15. Marks MN, Kumar R (1996) Infanticide in Scotland. Med. Sci. Law 36: 299-305.

16. Friedman SH, Heneghan A, Rosenthal M (2007) Characteristics of women who deny or conceal pregnancy. Psychosomatics 48: 117-22.

17. Stanton J, Simpson A, Wouldes T (2000) A qualitative study of filicide by mentally ill mothers. Child Abuse Negl 24: 1451-60.

18. Spinelli MG (2001) A systematic investigation of 16 cases of neonaticide. Am J Psychiatry 158: 811-3.

19. Howells JG (1972) Modern perspectives in psycho-obstetrics. Oliver \& Boyd, New York, USA.

20. Resnick PJ (1970) Murder of the newborn: A psychiatric review of neonaticide. Am J Psychiatry 126: 1414-20.

21. Betsos IM (2003) Demons of the hearth: wives and mothers who kill. Centro scientifico Editore, Torino.

22. Malmquist CP (2013) Infanticide/neonaticide: The outlier situation in the United States. Aggression and Violent Behavior 18: 399-408.

23. Krischer MK, Stone MH, Sevecke K, Steinmeyer EM (2007) Motives for maternal filicide: results from a study with female forensic patients. Int J Law Psychiatry 30: 191-200.

24. Haapasalo J, Petaja S (1999) Mothers who killed or attempted to kill their child: Life circumstances, childhood abuse and types of killing. Violence Vict 14: 219-39.

25. Putkonen H, Collander J, Weizmann-Henelius G, Eronen M (2007) Legal outcomes of all suspected neonaticides in Finland 1980-2000. Int J Law Psychiatry 30: 248-54.

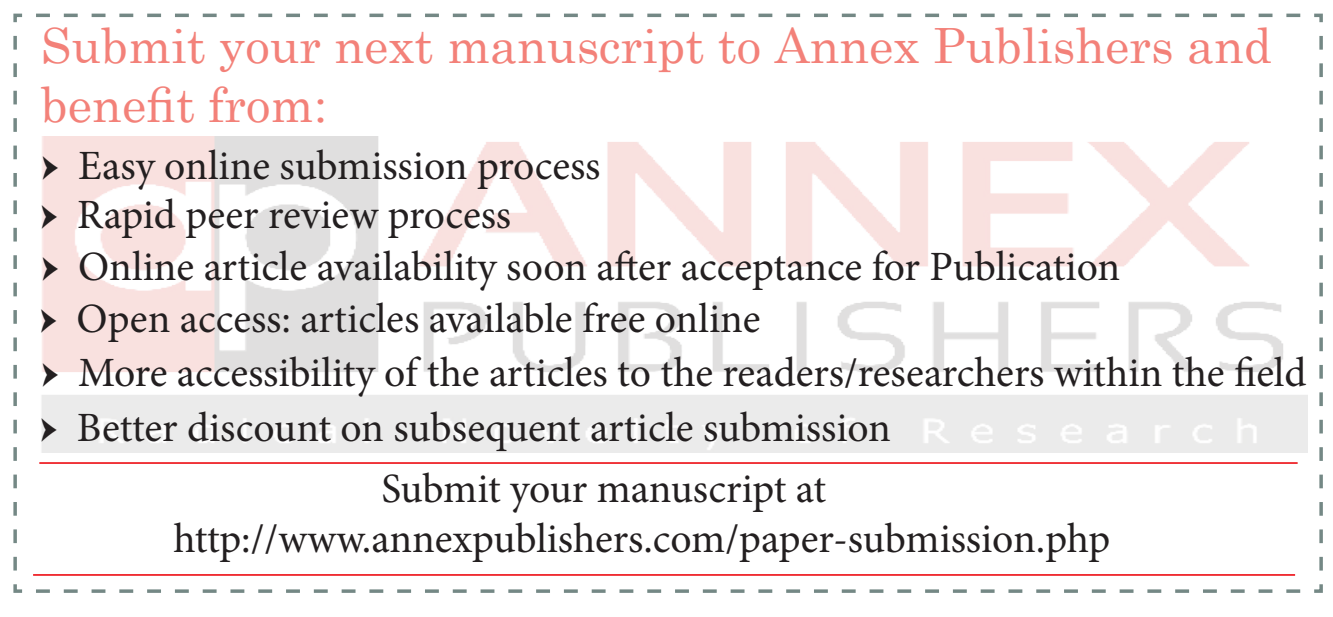

